\title{
Diversity analysis of BmNPV Isolates Infecting Mulberry Silkworm (Bombyx mori) using Restriction Endonuclease Digestion Profiling
}

\author{
N. Nagesha ${ }^{1 \searrow \odot}$, J. Natesh ${ }^{1}$, N. H. Meenakshi ${ }^{1}$, Anitha Peter $^{1}$ and V. Venkataravanappa ${ }^{2}$ \\ ${ }^{1}$ Dept. of Plant Biotechnology, College of Agriculture, University of Agricultural Sciences, GKVK, Bangalore (560 065), India \\ ${ }^{2}$ Dept. Plant Pathology, ICAR Indian Institute of Horticultural Research, Chettalli, Kodagu, Karnataka (571 248), India \\ Open Access \\ Corresponding $\$ nageshabt@gmail.com \\ 0000-0002-0562-4598

\section{ABSTRACT} \\ U \\ nderstanding the genetic diversity of $B m \mathrm{NPV}$ isolates causing grasserie viral disease of mulberry silkworm Bombyx mori \\ L. is essential for adoption of management strategies including biotechnological tools. The present study was aimed at \\ the use of restriction fragment length polymorphism (RFLP) profiling for studying the molecular diversity analysis of six \\ $B m$ NPV isolates collected from Devanahalli, Kolar, Shidlaghatta, Hosakote, Tumakuru, and Ramanagara areas in Karnataka, \\ India ( $B m \mathrm{NPV}-\mathrm{Ko}, B m \mathrm{NPV}-\mathrm{Ho}, B m \mathrm{NPV}-\mathrm{SG}, B m \mathrm{NPV}-\mathrm{DH}, B m \mathrm{NPV}-\mathrm{TM}, B m \mathrm{NPV}-\mathrm{Ram}$ respectively). DNA was extracted \\ from each of these isolates and subjected to digestion with different restriction enzymes EcoR1, BamH1, Sma1, Nco1, and a \\ combination of $B a m H 1+N c o 1$ and electrophoresed in $0.8 \% \mathrm{w} / \mathrm{v}$ agarose gel to visualize restriction enzyme profile. The analysis \\ revealed that all the six $B m \mathrm{NPV}$ isolates had similar $N_{c o} 1$ and $S m a 1$ restriction patterns, although there was variation in low \\ molecular weight fragments. The $E c o \mathrm{R} 1$ and $B a m \mathrm{H} 1$ restriction patterns were nearly the same for all the isolates except for \\ the presence of an approximately $4 \mathrm{~kb}$ and an additional $1.5 \mathrm{~kb}$ polymorphic band only in $B m$ NPV-TM and $B m$ NPV-Ram \\ isolates. $B a m \mathrm{H} 1+N c o 1$ digestion of the DNA from each isolate yielded numerous fragments, which was different in $B m \mathrm{NPV}$ - \\ Ram isolate. Molecular diversity analysis can helps in understanding the evolution and phylogeny of the virus, enhance the \\ knowledge on its pathogenicity and can help to develop and adopt suitable measures to combat and diagnose the disease to \\ reduce crop loss and increase income generating ability of the farmer.
}

KEYWORDS: Bombyx mori, diversity, Grasserie, NPV, restriction digestion, silkworm, virus

Citation (VANCOUVER): Nagesha et al., Diversity analysis of BmNPV Isolates Infecting Mulberry Silkworm (Bombyx mori) using Restriction Endonuclease Digestion Profiling. International Journal of Bio-resource and Stress Management, 2022; 13(1), 1-8. HTTPS://DOI. ORG/10.23910/1.2022.2352.

Copyright: (c) 2022 Nagesha et al. This is an open access article that permits unrestricted use, distribution and reproduction in any medium after the author(s) and source are credited.

Data Availability Statement: Legal restrictions are imposed on the public sharing of raw data. However, authors have full right to transfer or share the data in raw form upon request subject to either meeting the conditions of the original consents and the original research study. Further, access of data needs to meet whether the user complies with the ethical and legal obligations as data controllers to allow for secondary use of the data outside of the original study.

Conflict of interests: The authors have declared that no conflict of interest exists.

RECEIVED on $11^{\text {th }}$ May 2021 RECEIVED in revised form on $20^{\text {th }}$ December 2021 ACCEPTED in final form on $10^{\text {th }}$ January 2022 PUBLISHED on $25^{\text {th }}$ January 2022 


\section{INTRODUCTION}

$\mathrm{T}$ he silkworm Bombyx mori L. has been utilized for the production of silk which is generally referred as "queen of fabrics" due to its luster, softness, colour, biodegradability, elegance, biocompatibility, strength and flexible properties and also used as powerful biological model system. Globally silk production is estimated was $1,59,648 \mathrm{mt}$ (2018). China is lead producer of silk $(1,20,000$ $\mathrm{mt} / 75.16 \%)$ followed by India (35,261 MT/22.08\%) (Anonymous, 2018). The silkworm Bombyx mori is highly susceptible to multiple diseases caused by protozoa, virus, bacteria and fungi pathogens. The disease caused by Bombyx mori nuclear polyhedrosis virus (Bm NPV) causes drastic damage in the cocoon yield affecting the income of silkworm growers. Grasserie disease causes more than $15 \%$ loss in yield and accounts for $25-58 \%$ in total disease incidence (Sharma et al., 2014). The NPV infects various tissues, and multiplies in the nucleus forming inclusion bodies called polyhedra, which are occluded viral particles (Jiang et al., 2012).

$B m \mathrm{NPV}$ is arthropod-specific, enveloped, rod-shaped virus belonging to the family Baculoviridae characterized by a circular, supercoiled and dsDNA-containing genome infecting lepidoptera group of insects (Kool et al., 1995; Gomi et al., 1999). BmNPV is well characterized baculoviruses with a genome of $132 \mathrm{~kb}$ in size (Palhan and Gopinathan, 1996) with a biphasic life cycle, two virion phenotypes are formed such as occlusion-derived virus (ODV) and budded virus (BV). ODV is involved in the lateral transmission between individuals whereas $\mathrm{BV}$ plays an important role in spreading the infection throughout the host (Wang et al., 2018).

Phylogenetic analysis of common ORFs of six strains of $B m$ NPV were studied in which the genome of the Indian strain consisted of 126,879 nucleotides, with a $40.4 \%$ of $\mathrm{G}+\mathrm{C}$. Variation in terms of survival rate, virulence and host range has been well documented among isolates of Heliothis NPVs (Bilimoria, 1983). Sub molar fragments have been reported by restriction digestion of a wild isolate of $A c N P V$, which resulted in the isolation of several variants of the particular isolate (Summers and Smith, 1978; Lee and Miller, 1978). Similarly, the RFLP profiles of MNPV genome from $A$. californica, Tricoplusia ni, Rachiplusia ou and Galleria mellonella has been well studied (Smith and Summers, 1979; 1980). Further, RFLP, was used to study the genetic variation within Malacosoma californicum pluviale NPV wild type populations (Cooper et al., 2003).

Chateigner et al. (2015) reported that the population polymorphisms are essential for functional diversity in model baculovirus Autographa californica multiple nucleopolyhedrovirus (AcMNPV). The major factors required for the adaptation during virus-host interaction is genetic variation (Obbard and Dudas, 2014; Holmes, 2011). Categorization of different isolates of SfMNPV and ensuring their field efficacy polymorphism exhibited by the isolates proved to be very essential (Alletti et al., 2017).

Restriction digestion analysis helps in studying the polymorphisms among different organisms in which, RFLP was used extensively to study the polymorphism in NPVs (Herniou et al., 2003). The highly polymorphic nature of NPVs has led to study the diversity of BmNPV. The RFLP technique was used to analyze the NPV genomes by using different restriction enzymes to differentiate the AcNPV, Orgyia pseudotsugata nuclear polyhedrosis virus $(O p N P V)$ and Helicoverpa zea nuclear polyhedrosis virus (HzNPV) associated with different insect hosts. These NPVs wee used as bio-pesticide formulations in different combinations, without affecting the quality of the pesticides as there is a lot of specificity between the NPV strains and the host they infect (Miller and Dawes, 1978). Restriction digestion of $\mathrm{PCR}$ products of $25 \mathrm{kbp}$ region using different restriction enzymes showed genetic diversity among the 7 Heliothis armigera nuclear polyhedrosis virus (HearNPV) isolates (Mehrvar et al., 2008). The polyhedron (polb) gene encoding structural protein of the occlusion bodies was used to study the diversity of the distinct isolates of HearNPV by PCR analysis (Singh et al., 2019). The five $\mathrm{BmNPV}$ isolates were characterized based on the amplified fragment length polymorphism pattern (AFLP) using four AFLP primer combinations (Peter et al., 2016). Diversity analysis of $B m \mathrm{NPV}$ could help in studying its evolution and phylogeny and its diagnostics.

Hence, the present investigation is undertaken to study the diversity analysis of $B m \mathrm{NPV}$ isolates procured from different silkworm growing areas of Karnataka using restriction endonuclease digestion profiling analysis.

\section{MATERIALS AND METHODS}

\subsection{Collection of $B m N P V$ isolates}

The $B m$ NPV infected silkworms were collected from six different districts of Karnataka viz., Devanahalli (Latitude: $13^{\circ} 14^{\prime} 47.58^{\prime \prime} \mathrm{N}$; Longitude: $77^{\circ} 42$ ' 42.59" E), Kolar (Latitude: $13^{\circ} 07^{\prime} 48.00^{\prime \prime} \mathrm{N}$; Longitude: $78^{\circ}$ $07^{\prime} 48.00^{\prime}$ E), Shidlaghatta (Latitude: $13^{\circ} 23^{\prime} 24.00^{\prime \prime} \mathrm{N}$; Longitude: $\left.77^{\circ} 51^{\prime} 36.00^{\prime \prime} \mathrm{E}\right)$, Hosakote (Latitude: $13^{\circ}$ 04' 14.52" N; Longitude: $77^{\circ} 47^{\prime} 53.30^{\prime \prime}$ E), Tumakuru (Latitude: $13^{\circ} 20^{\prime} 28.90 " N$; Longitude: $77^{\circ} 06^{\prime} 7.92 ” \mathrm{E}$ ), Ramanagara (Latitude: $12^{\circ} 42$ ' 34.02" N; Longitude: $12^{\circ}$ 42' 34.02” E) during the year 2016-2018. The silkworms were collected based on their symptoms caused by $B m \mathrm{NPV}$. The research was conducted at Department of Plant Biotechnology, College of Agriculture, UAS (B), GKVK, Bangalore-560065, Karnataka, India. 


\subsection{Preparation of polyhedra and purification of virions}

A modified standard protocol was followed for the isolation of $B m$ NPV viral DNA (Govindan et al., 1998). The NPV infected silkworms were used for the collection of turbid milky haemolymph by cutting the front pair of prolegs and stored in sterilized glass tubes followed by immediate refrigeration. The haemolymph was then diluted two fold by adding distilled water and filtered through double layer cheese cloth and centrifuged at 12,000 RPM for $15 \mathrm{~min}$ at $4^{\circ} \mathrm{C}$. After centrifugation, the pellet was resuspended in sterile distilled water and centrifuged at 5,000 RPM for $15 \mathrm{~min}$ at $4^{\circ} \mathrm{C}$. Repeated cycles of centrifugation at 12,000 $\mathrm{RPM}$ and 5,000 RPM was done for 15 min each to get milky white amorphous sediment of nuclear polyhedra. The polyhedra were suspended in distilled water and stored. The different sucrose gradients layers of 60,55 , 50,45 , and $40 \%$ (W/W) sucrose solution were prepared in Beckman $5 \mathrm{ml}$ centrifuge tubes and incubated at $4^{\circ} \mathrm{C}$ overnight. Further, three $\mathrm{ml}$ of amorphous sediment of nuclear polyhedra was loaded on to the sucrose gradient and ultra-centrifuged at 32,000 RPM for $60 \mathrm{~min}$ at $4^{\circ} \mathrm{C}$. The pellet was collected and dissolved in $1.5 \mathrm{ml}$ of distilled water.

\subsection{Isolation of DNA from purified virions}

The re-suspended polyhedral pellet obtained from the ultra-centrifugation was pelleted by centrifugation at 9000 RPM for $2 \mathrm{~min}$. The pellet was re-suspended in $200 \mu \mathrm{l}$ distilled water. $20 \mu 1$ of $0.5 \mathrm{M}$ EDTA and $2 \mathrm{ml}$ of proteinase $\mathrm{K}$ were added and incubated for 5 hours. Half the volume of sodium carbonate $(0.1 \mathrm{M})$ was added and incubated at $37^{\circ} \mathrm{C}$ for $15 \mathrm{~min}, 20 \mathrm{ml}$ of $10 \% \mathrm{w} / \mathrm{v}$ SDS was added and incubated at $37^{\circ} \mathrm{C}$ for $15 \mathrm{~min}$ and centrifuged for $30 \mathrm{~s}$ at 6500 RPM, the supernatant was collected in a clean test tube. An equal volume of Tris-saturated phenol was added and gently agitated for 2 min followed by centrifugation at $9000 \mathrm{RPM}$ for $2 \mathrm{~min}$. The upper phase was removed carefully and transferred to a clean tube without disturbing the interface. An equal volume of 25:24:1 Tris-saturatedphenol: chloroform: isoamylalcohol was added and gently agitated for 2 min followed by centrifugation at 9000 RPM for $2 \mathrm{~min}$; the upper phase was removed carefully and transferred to a clean tube without disturbing the interface. To the supernatant, 2.5 times absolute alcohol was added and incubated at $-20^{\circ} \mathrm{C}$ overnight and then the pellet was collected after centrifugation at 9000 RPM. The supernatant was removed and pellet was dried and dissolved in nuclease free water and stored in a $-20^{\circ} \mathrm{C}$ freezer. $5 \mu \mathrm{l}$ of isolated $B m \mathrm{NPV}$ viral DNA was mixed with $1 \mu \mathrm{l}$ of loading dye and electrophoresed in $0.8 \% \mathrm{w} / \mathrm{v}$ gel in TAE buffer along with $1 \mathrm{~Kb}$ ladder and then run at $70 \mathrm{~V}$ for 1 hour $30 \mathrm{~min}$. The DNA bands in the gel were visualized on a UV- Transilluminator.

\subsection{Restriction endonuclease profiling}

The purified $B m$ NPV DNA was used for restriction analysis using the different restriction enzymes. The reaction mixure consisted of $B m \mathrm{NPV}$ DNA, 10x NEB cut smart buffer, different restriction enzymes viz., EcoR1, BamH1, Sma1, Nco1, and BamH1+Nco1 (20 units), and nuclease free water. The reaction mixture was incubated at $37^{\circ} \mathrm{C}$ for $3 \mathrm{~h}$ and then inactivated at $60^{\circ} \mathrm{C}$ for $20 \mathrm{~min}$. The restriction digested sample was then run on $0.8 \%$ $\mathrm{w} / \mathrm{v}$ agarose gel to visualize restriction enzyme profiling. The polymorphic bands were scored as presence (1) or absence (0) of bands. The analyses were performed using NTSYS-pc software, version 2.0 (Rolhf, 1990). The data matrix was used to calculate Jaccard's similarity coefficient (Sneath and Sokal 1973) which does not consider the joint absence of a marker as an indication of similarity. A dendrogram was constructed using the unweighted pair group method analysis (UPGMA). The frequencies of the RFLP fragments were estimated for each of the $B m \mathrm{NPV}$ isolates infecting silkworm.

\section{RESULTS AND DISCUSSION}

\subsection{Purification and isolation of $B m N P V$ viral $D N A$}

The haemolymph from $B m$ NPV infected worms collected from different regions of Southern Karnataka as purified by differential centrifugation and sucrose density gradient centrifugation and the presence of $B m \mathrm{NPV}$ polyhedra's were confirmed under compound microscope (100x) (Plate 1). Viral DNA isolated from purified polyhedra was confirmed by gel electrophoresis (Figure 1).

\subsection{Restriction endonuclease profiling of BmNPV viral genome}

The total viral DNA isolated from the six $B m$ NPV isolates (BmNPV-Ko, BmNPV-Ho, BmNPV-SG, BmNPV-DH,

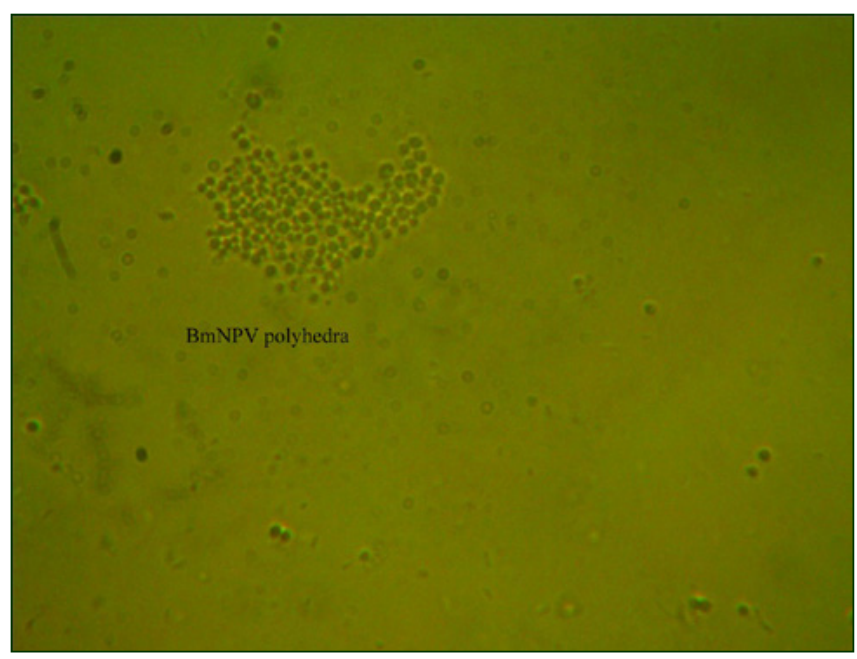

Plate 1: Confirmation of presence of $B m N P V$ polyhedra under 100x compound microscope 


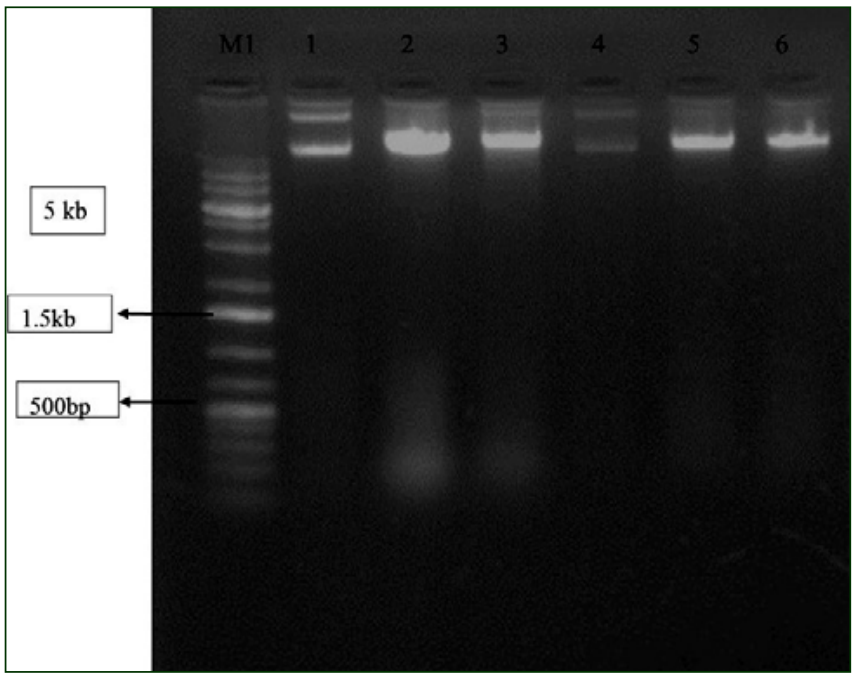

Figure 1: Ethidium bromide stained agarose gel showing viral DNA isolated from $B m \mathrm{NPV}$ infected silkworms collected from different locations of Karnataka.

Lane M 1:1 Kb ladder; Lane 1: Kolar isolate; Lane 2: Tumakur isolate; Lane 3: Shidlaghatta isolate; Lane 4: Devanahalli isolate; Lane 5: Hosakote isolate; Lane 6: Ramanagar isolate

$B m$ NPV-TM, $B m$ NPV-Ram) were digested with different restriction enzymes which includes EcoR1, BamH1, Sma1, $N_{c o} 1$, and $B a m \mathrm{H} 1+N_{c o} 1$ as they were previously used in similar studies (Hong et al., 2000) (Figure 2-6). The restriction profiles of each enzyme are shown in Table 1. All the six $B m \mathrm{NPV}$ isolates had a quite similar $N_{c o 1}$ and $S m a 1$ restriction patterns, although low molecular fragments showed a minor difference. Whereas EcoR1 and

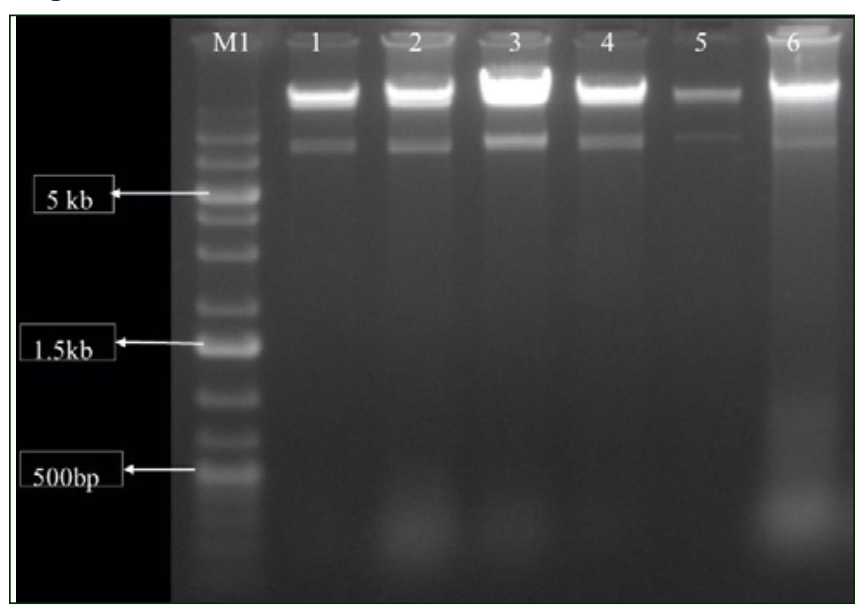

Figure 2: Ethidium bromide stained agarose gel showing restriction endonuclease profiling of $B m \mathrm{NPV}$ isolates using Sma1 enzyme.

M 1: 1 Kb ladder; Lane 1: Kolar isolate; Lane 2: Tumakuru isolate; Lane 3: Shidlaghatta isolate; Lane 4: Devanahalli isolate; Lane 5: Hosakote isolate; Lane 6: Ramanagara isolate

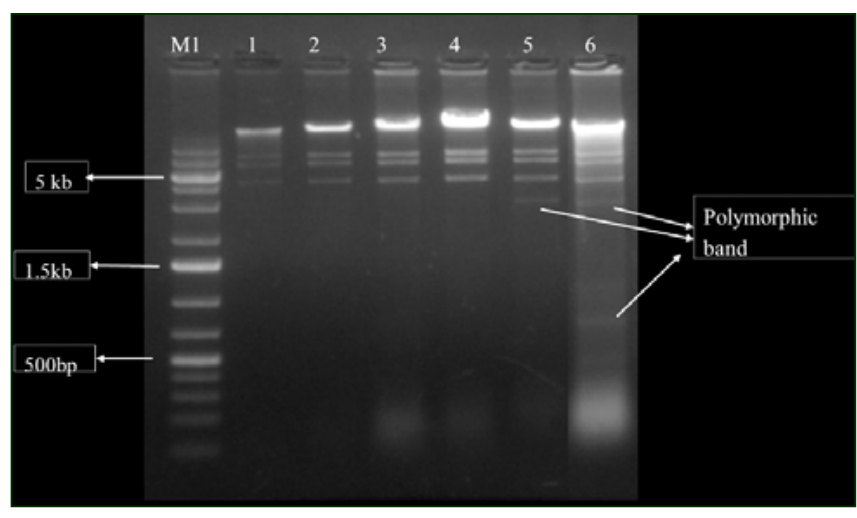

Figure 3: Ethidium bromide stained agarose gel showing restriction endonuclease profiling of $B m \mathrm{NPV}$ isolates using BamH1 enzyme.

M 1: $1 \mathrm{~Kb}$ ladder; Lane 1: Kolar isolate; Lane 2: Hosakote isolate; Lane 3: Shidlaghatta isolate; Lane 4: Devanahalli isolate; Lane 5: Tumakuru isolate; Lane 6: Ramanagar isolate

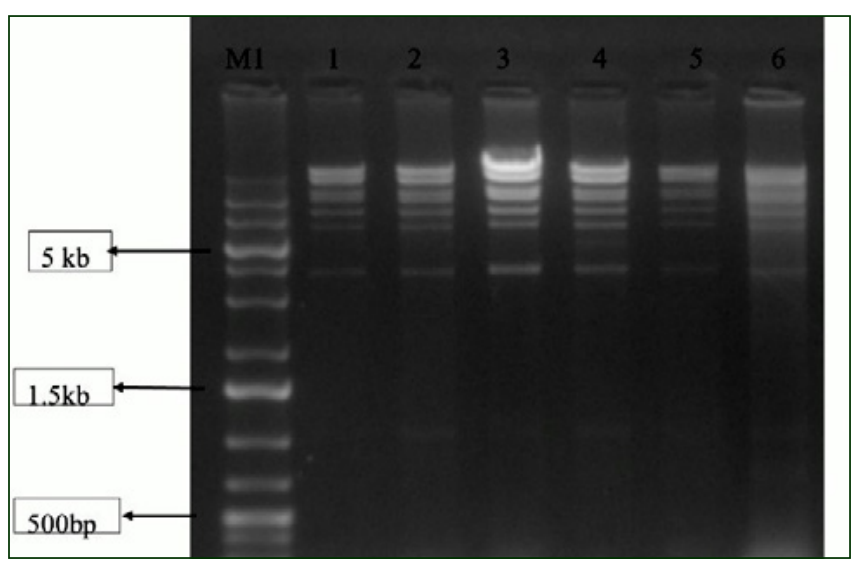

Figure 4: Ethidium bromide stained agarose gel showing restriction endonuclease profiling of $B m \mathrm{NPV}$ isolates using Nco1 enzyme.

M1:1 Kb ladder; Lane 1: Kolar isolate; Lane 2: Hosakote isolate; Lane 3: Shidlaghatta isolate; Lane 4: Devanahalli isolate; Lane 5: Tumakuru isolate; Lane 6: Ramanagara isolate

Bam $\mathrm{H} 1$ restriction patterns were nearly the same for all the six isolates except for the presence of an approximately of $4 \mathrm{~kb}$ band and an additional $1.5 \mathrm{~kb}$ polymorphic band observed only in BmNPV-TM and BmNPV-Ram isolates. Similarly, BamH1+Nco1 digestion of the DNAs from each isolate yielded numerous fragments, and $B a m \mathrm{H} 1+N_{c o} 1$ patterns were different in BmNPV-Ram isolate. Based on the scores, a dendrogram was drawn (Figure 7) using XLSTAT software which represented the relationship among six isolates of $B m \mathrm{NPV}$ containing two large clusters. BmNPV-Ram isolate was present in one cluster, while the other cluster contained two sub-clusters one with $B m$ NPV-TM isolate and the other with $B m$ NPV-Ko, 


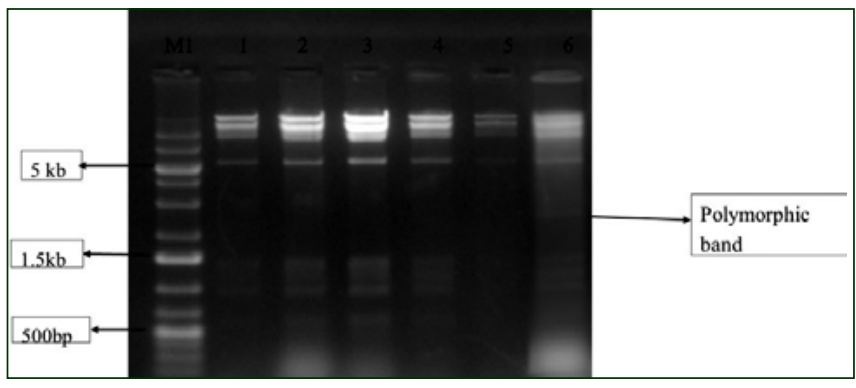

Figure 5: Ethidium bromide stained agarose gel showing restriction endonuclease profiling of $B m \mathrm{NPV}$ isolates using EcoR1 enzyme.

M1:1 Kb ladder; Lane 1: Kolar isolate; Lane 2: Hosakote isolate; Lane 3: Shidlaghatta isolate; Lane 4: Devanahalli isolate; Lane 5: Tumakuru isolate; Lane 6: Ramanagara isolate

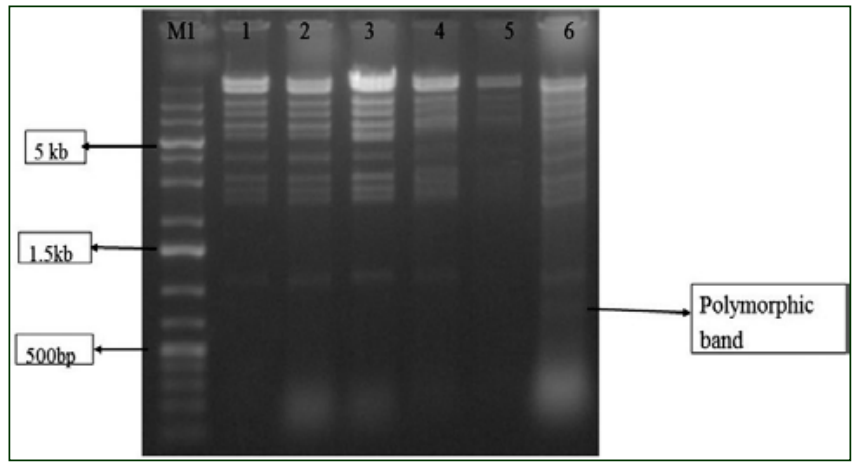

Figure 6: Ethidium bromide stained agarose gel showing restriction endonuclease profiling of $B m \mathrm{NPV}$ isolates using Bam $\mathrm{H} 1+\mathrm{Nco} 1$ enzyme.

M1:1 Kb ladder; Lane 1: Kolar isolate; Lane 2: Hosakote isolate; Lane 3: Shidlaghatta isolate; Lane 4: Devanahalli isolate; Lane 5: Tumakuru isolate; Lane 6: Ramanagara isolate

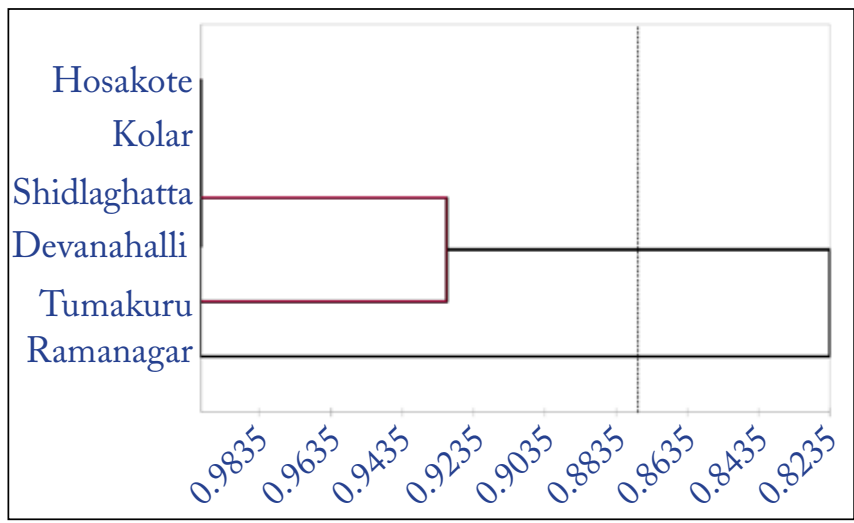

Figure 7: Dendrogram representing relationship among six $B m \mathrm{NPV}$ isolates

$B m \mathrm{NPV}-\mathrm{Ho}, B m \mathrm{NPV}-\mathrm{SG}$ and $B m \mathrm{NPV}-\mathrm{DH}$ isolates. Similarity indices of the values between the six isolates are shown in Table 2. The RFLP profile analysis of viral DNA has been used to distinguish and characterize closely related genotypic variants and species (Hong et al., 2000). In the present study, six $B m \mathrm{NPV}$ isolates ( $B m \mathrm{NPV}-\mathrm{Ko}$, $B m$ NPV-Ho, $B m$ NPV-SG, $B m$ NPV-DH, $B m$ NPV-TM, $B m$ NPV-Ram) isolated from $B$. mori are closely related but slightly different with respect to EcoR1 and BamH1 enzyme profiles. These variations may be due to insertion of host DNA into the viral genome or deletions / point mutations in the viral DNA.

AFLP markers were used to understand the diversityof $B m$ NPV isolates collected from different locations of Karnataka (Peter et al., 2016). Palhan and Gopinathan (1996) found distinct differences for restriction enzyme Hind III profile for Bangalore (BLR) and Dharwad (DHR) isolates of $B m \mathrm{NPV}$ in Karnataka. Hong et al. (2000) also

Table 1: Restriction digestion banding pattern of $B m$ NPV DNA ( $B m$ NPV-Ko, $B m$ NPV-Ho, $B m$ NPV-SG, $B m$ NPVDH, $B m$ NPV-TM, $B m$ NPV-Ram) with different restriction enzymes

\begin{tabular}{llcccccc}
\hline $\begin{array}{l}\text { Restriction } \\
\text { enzymes }\end{array}$ & $\begin{array}{l}\text { Band } \\
\text { Size }\end{array}$ & $\begin{array}{c}\text { BmNPV- } \\
\text { Ko }\end{array}$ & $\begin{array}{c}B m \text { NPV- } \\
\text { Ho }\end{array}$ & $\begin{array}{c}B m \text { NPV- } \\
\text { SG }\end{array}$ & $\begin{array}{c}\text { BmNPV- } \\
\text { DH }\end{array}$ & BmNPV-TM & BmNPV-RAM \\
\hline BamH1 & $>10 \mathrm{~kb}$ & 1 & 1 & 1 & 1 & 1 & 1 \\
& $9 \mathrm{~kb}$ & 1 & 1 & 1 & 1 & 1 & 1 \\
& $8 \mathrm{~kb}$ & 1 & 1 & 1 & 1 & 1 & 1 \\
& $5.8 \mathrm{~kb}$ & 1 & 1 & 1 & 1 & 1 & 1 \\
& $4 \mathrm{~kb}$ & 0 & 0 & 0 & 0 & 1 & 1 \\
& $1.5 \mathrm{~kb}$ & 0 & 0 & 0 & 0 & 0 & 1 \\
& $11 \mathrm{~kb}$ & 1 & 1 & 1 & 1 & 1 & 1 \\
& $9.5 \mathrm{~kb}$ & 1 & 1 & 1 & 1 & 1 & 1 \\
& $9 \mathrm{~kb}$ & 1 & 1 & 1 & 1 & 1 & 1 \\
& $6.3 \mathrm{~kb}$ & 1 & 1 & 1 & 1 & 1 & 1 \\
& $3.5 \mathrm{~kb}$ & 0 & 0 & 0 & 0 & 0 & 1 \\
\hline
\end{tabular}




\begin{tabular}{|c|c|c|c|c|c|c|c|}
\hline $\begin{array}{l}\text { Restriction } \\
\text { enzymes }\end{array}$ & $\begin{array}{l}\text { Band } \\
\text { Size }\end{array}$ & $\begin{array}{c}B m \text { NPV- } \\
\text { Ko }\end{array}$ & $\begin{array}{c}B m \mathrm{NPV}- \\
\mathrm{Ho}\end{array}$ & $\begin{array}{c}B m \mathrm{NPV}- \\
\mathrm{SG}\end{array}$ & $\begin{array}{c}B m \mathrm{NPV}- \\
\mathrm{DH}\end{array}$ & $B m$ NPV-TM & $B m$ NPV-RAM \\
\hline \multirow[t]{2}{*}{ Sma1 } & $>10 \mathrm{~kb}$ & 1 & 1 & 1 & 1 & 1 & 1 \\
\hline & $8 \mathrm{~kb}$ & 1 & 1 & 1 & 1 & 1 & 1 \\
\hline \multirow[t]{6}{*}{ Nco1 } & $>10 \mathrm{~kb}$ & 1 & 1 & 1 & 1 & 1 & 1 \\
\hline & $10 \mathrm{~kb}$ & 1 & 1 & 1 & 1 & 1 & 1 \\
\hline & $9 \mathrm{~kb}$ & 1 & 1 & 1 & 1 & 1 & 1 \\
\hline & $7.8 \mathrm{~kb}$ & 1 & 1 & 1 & 1 & 1 & 1 \\
\hline & $7 \mathrm{~kb}$ & 1 & 1 & 1 & 1 & 1 & 1 \\
\hline & $5 \mathrm{~kb}$ & 1 & 1 & 1 & 1 & 1 & 1 \\
\hline \multirow[t]{12}{*}{$B a m \mathrm{H} 1+N c o 1$} & $>10 \mathrm{~kb}$ & 1 & 1 & 1 & 1 & 1 & 1 \\
\hline & $10 \mathrm{~kb}$ & 1 & 1 & 1 & 1 & 1 & 1 \\
\hline & $9 \mathrm{~kb}$ & 1 & 1 & 1 & 1 & 1 & 1 \\
\hline & $8 \mathrm{~kb}$ & 1 & 1 & 1 & 1 & 1 & 1 \\
\hline & $7.5 \mathrm{~kb}$ & 1 & 1 & 1 & 1 & 1 & 1 \\
\hline & $7 \mathrm{~kb}$ & 1 & 1 & 1 & 1 & 1 & 1 \\
\hline & $5 \mathrm{~kb}$ & 1 & 1 & 1 & 1 & 1 & 1 \\
\hline & $4.3 \mathrm{~kb}$ & 1 & 1 & 1 & 1 & 1 & 1 \\
\hline & $4 \mathrm{~kb}$ & 1 & 1 & 1 & 1 & 1 & 1 \\
\hline & $3.8 \mathrm{~kb}$ & 1 & 1 & 1 & 1 & 1 & 1 \\
\hline & $2.2 \mathrm{~kb}$ & 1 & 1 & 1 & 1 & 1 & 1 \\
\hline & $2 \mathrm{~kb}$ & 0 & 0 & 0 & 0 & 0 & 1 \\
\hline
\end{tabular}

\begin{tabular}{lcccccc}
\hline \multicolumn{6}{l}{ Table 2: Similarity indices of six } & $B m$ NPV isolates collected from different locations of Karnataka \\
\hline & Kolar & Hosakote & Shidlaghatta & Devanahalli & Tumakuru & Ramanagara \\
\hline Kolar & 1.000 & & & & & \\
Hosakote & 1.000 & 1.000 & & & & \\
Shidlaghatta & 1.000 & 1.000 & 1.000 & & & \\
Devanahalli & 1.000 & 1.000 & 1.000 & 1.000 & & \\
Tumakuru & 0.964 & 0.964 & 0.964 & 0.964 & 1.000 & 1.000 \\
Ramanagar & 0.871 & 0.871 & 0.871 & 0.871 & 0.871 & \\
\hline
\end{tabular}

used restriction endonuclease analysis of $B m N P V$ viral DNA which has been used to distinguish and characterize closely related genotypic variants and observed that $B m \mathrm{NPV}$ isolates from wild stocks were closely related with slightly different banding pattern. Similar differences in RFLP profile for multiple peptide occlusion nuclear polyhedrosis virus (MNPV) and single peptide occlusion nuclear polyhedrosis virus (SNPV) infecting Heliothis and Orygyia pseudotsugata respectively have been reported (Rohrmann and Beaudreau, 1977) also for Tricoplusia ni (Smith and Summers, 1979). These minor genotypic variations serve as genetic markers for the particular isolate. HearNPV isolates of Spain and Portugal showed genetic variations based on their restriction fragment profile (Figueiredo et al., 1999). Restriction endonuclease analysis of Spodoptera litura NPV and S. littoralis NPV from Japan, Vietnam, Malaysia, India, and Egypt (Takatsuka et al., 2003) also revealed similar findings.

Genomic diversity acts a major determinant of viral evolutionary dynamics and virulence (Geoghegan and Holmes, 2018), particularly large DNA viruses (Renner and Szpara 2017). Mason et al. (2021) characterized the genetic diversity analysis of SfMNPV populations and showed that coding regions with higher genetic diversity are associated with oral infectivity or unknown functions. 
Thus variation in baculoviruses has been observed between geographical regions, within virus isolates, within single agricultural fields, between different polyhedra in a single host and polymorphism has also been detected in baculovirus genotypes, derived from a single isolate. Variation has also been noticed in the pathogenicity of the virus (Williams and Payne, 1984; Bilimoria, 1983; Burgess, 1977; Smith and Summers, 1979). Thus molecular markers can be used for better understanding the biodiversity of the $B m \mathrm{NPV}$, their evolution patterns and recombination. It could also help in developing better immunodiagnostic kits for the identification of $B m \mathrm{NPV}$ and better management of the disease.

\section{CONCLUSION}

Cix $B m \mathrm{NPV}$ isolates (BmNPV-Ko, $B m \mathrm{NPV}-\mathrm{Ho}$, S $m m$ NPV-SG, $B m$ NPV-DH, $B m$ NPV-TM, $B m$ NPVRam) isolated from mulberry silkworm $B$. mori from different locations were found to be closely related but slightly different with respect to EcoR1 and BamH1 enzyme profiles. These variations may be due to insertion of host DNA into the viral genome or deletions / point mutations in the viral DNA.

\section{FUTURE RESEARCH}

Gurther analysis of these genetic variation will lead

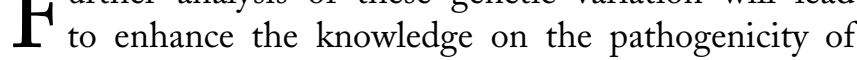
$B m \mathrm{NPV}$ and developing suitable measures to combat and diagnose the disease. These genetic diversity of $B m \mathrm{NPV}$ isolates will be further validated by studying the expression of antiviral protein genes in silkworm from the respective locations.

\section{ACKNOWLEDGEMENT}

$\mathrm{W}$ e are gratefully acknowledge the Science and Engineering Research Board (SERB), Department of Science and Technology, Government of India, New Delhi for providing financial support to carry out the research work (Project SERB File Number: YSS/2014/000146). Present investigation was done during 2016 to 2018.

\section{REFERENCES}

Alletti, G.G., Sauer, A.J., Weihrauch, B., Fritsch, E., Undorf-Spahn, K., Wennmann, J.T., Jehle, J.A., 2017. Using next generation sequencing to identify and quantify the genetic composition of resistancebreaking commercial isolates of cydia pomonella granulovirus. Viruses 9(9), 250.

Anonymous, 2018, International sericultural commission (ISC) Statistical Report. Available at https://inserco. org/en/statistics. Accessed on 13.11.2018

Bilimoria, S.L., 1983. Genomic divergence among singlenucleocapsid nuclear polyhedrosis viruses of plusiine hosts. Virology 127, 15-23.

Burgess, S., 1977. Molecular weights of lepidopteran baculoviruses DNAs: derivation by electron microscopy. Journal of General Virology 37, 501-510.

Chateigner, A., Bezier, A., Labrousse, C., Jiolle, D., Barbe, V., Herniou., E.A., 2015. Ultra deep sequencing of a baculovirus population reveals widespread genomic variations." Viruses 7(7), 3625-3646.

Cooper, D., Cory, J.S., Myers, J.H., 2003. Hierarchical spatial structure of genetically variable nucleopolyhedro viruses infecting cyclic populations of western tent caterpillars. Molecular Ecology 12, 881-890.

Figueiredo, E., Munoz, D., Escribano, A., Mexia, A., Vlak, J.M., Caballero, P., 1999. Biochemical identification and comparative insecticidal activity of nucleopolyhedrosisvirus isolates pathogenic for Heliothis armigera (Lepdidoptera: Noctuidae) larvae. Journal of Applied Entomology 123, 165-169.

Geoghegan, J.L., Holmes, E.C., 2018. The phylogenomics of evolving virus virulence. Nature Reviews Genetics 19(12), 756-769.

Gomi, S., Majima, K., Maeda, S., 1999. Sequence analysis of the genome of Bombyx mori nucleopolyhedro virus. Journal of General Virology 80, 1323-1337.

Govindan, R., Narayanaswamy, K.C., Devaiah, M.C., 1998. Principles of silkworm pathology, In: Seri scientific publishers, Bangalore, 65

Herniou, E.A., Olszewski, J.A., Cory, J.S., O'reilly, D.R., 2003. The genome sequence and evolution of baculoviruses. Annual Review of Entomology 48, 211-234.

Holmes, E.C., 2011. What does virus evolution tell us about virus origins?. Journal of Virology 85(11), 5247-5251.

Hong, H.K., Woo, S.D., Choi, J.Y., Lee, H.K., Kim, M.H., Je, Y.H., Kang, S.K., 2000. Characterization of four isolates of Bombyx mori nucleopolyhedrovirus . Archieves of Virology 145, 2351-2361

Jiang, L., Cheng, T.C., Zhao, P., Yang, Q., Wang, G.H., Jin, S.K., Lin, P., Xiao, Y., Xia, Q.Y., 2012. Resistance to $B m$ NPV via overexpression of an exogenous gene controlled by an inducible promoter and enhancer in transgenic silkworm, Bombyx mori. PLoS ONE 7(8), 1-9.

Kool, M., Ahrens, C.H., Vlak, J.M., Rohrmann, G.F., 1995. Replication of baculovirus DNA. Journal of General Virology 76, 2103-2118.

Lee, H.H., Miller, L.K., 1978. Isolation of genotypic variants of Autographa californica nuclear polyhedrosis virus. Journal of Virology 27, 754-767. 
Masson, T., Fabre, M.L., Pidre, M.L., Niz, J.M., Berretta, M.F., Romanowski, V., Ferrelli, M.L., 2021. Genomic diversity in a population of spodoptera frugiperda nucleopolyhedrovirus. Infection, Genetics and Evolution 90, 104749.

Mehrvar, A., Rabindra, R.J., Veena Kumari, K., Narabenchi, G.B., 2008. Molecular and biological characterisitics of some geographic isolates of nucleopolyhedrovirus of Helicoverpa armigera (Lepidotera: Noctuidae). Journal of Entomology Society Iran 28, 39-60.

Miller, L.K., Dawes, K.P., 1978. Restriction endonuclease analysis for the identification of baculovirus pesticides. Applied Environmental Microbiology 35, 411-421.

Obbard, D.J., Dudas, G., 2014. The genetics of host-virus coevolution in invertebrates. Current Opinion in Virology 8, 73-78.

Palhan, V.B., Gopinathan, K.P., 1996. Characterization of a local isolate of Bombyx mori nuclear polyhedrosis virus. Current Science 70, 147-153.

Peter, A., Patil, P., Shamprasad, P., Chandramohan, J., Shantala, J., Venkatesh, S.C., Gowda, K.S.M., 2016. Molecular diversity of Bombyx mori nuclear polyhedrosis virus ( $B m \mathrm{NPV})$ isolates using AFLP markers. Indian Journal of Ecology 43(1), 119-123.

Renner, Daniel, W., Szpara, M.L., 2017. Impacts of genome-wide analyses on our understanding of human herpesvirus diversity and evolution. Journal of Virology 92(1), 1-13.

Rolhf, F.J., 1990. NTSYSPc, Numerical taxonomy and multivariant analysis system. Version 2.02. Appl. Biostatics New York.

Rohrmann, G.F., Beaudreau, G.S., 1977. Characterization of DNA from polyhedral inclusion bodies of the nucleopolyhedrosis single-rod virus pathogenic for Orgyia pseudotsugata. Virology 83, 474-478.
Sharma, R., Ganie, N.A., Rufaie, Z.H., Khan, I.L., Parkash, J., 2014. Screening of various bivoltine hybrids of silkworm Bombyx mori L. for disease susceptibility during monsoon season in Uttar Pradesh, International Journal of Advanced Biotechnolgy Research 4(3), 352-356.

Singh, R., Jagadish, K.S., Kheta, R.T., Peter, A., 2019. Genetic diversity among different geographical isolates of the gram pod borer, Helicoverpa armigera (Hubner) (Lepidoptera: Noctuidae) nucleopolyhedrosis virus (HearNPV). Egyptian Journal of Biological Pest Control 29(61), 1-12.

Smith, G.E., Summers, M., 1979. Restriction maps of five Autographa californica MNPV variants, Trichoplusia ni MNPV, and Galleria mellonella MNPV DNAs with endonucleases SmaI, KpnI, BamHI, SacI, XhoI and EcoRI. Journal of Virology 30, 828-838.

Smith, G.E., Summers, M.D., 1980. Restriction map of Rachiplusia ou and Autographa californica baculovirus recombinants Journal of Virology 33, 311-319.

Sneath, P.A., Sokal, R.R., 1973. Numerical taxonomy. Freeman, San Francisco, 573.

Summers, M.D., Smith, G.E., 1978. Baculovirus structural polypeptides. Virology 84, 390-402.

Takatsuka, J., Okuno, S., Nakai, M., Kunimi, Y., 2003. Genetic and biological comparisons of ten geographical isolates of a nucleopolyhedrosis virus that infects Spodoptera litura (Lepidoptera: Noctuidae). Biological Control 26, 32-39.

Wang, L., Xiao, Q., Zhou, X.L., Zhu, Y., Dong, Z.Q., Chen, P., Pan, M.H., Cheng, L., 2018. Bombyx mori Nuclear Polyhedrosis Virus (BmNPV) induces host cell autophagy to benefit infection. Viruses 10, 14.

Williams, C.F., Payne, C.C., 1984. The susceptibility of Heliothis armigera larvae to three nuclear polyhedrosis viruses. Annuals of Applied Biology 104, 405-412. 